\section{MORPHOLOGY AND COMPOSITION ANALYSIS OF ENAMEL SURFACE WITH DENTAL ADHESIVE FOLLOWING THE APPLICATION OF ND:YAG ABLATION}

Fatanah M. Suhaimia*, Nurul Atiqah A. Razaka, Nur Syazana Azizana, Mohd Aizat Abu Bakarb, Mohammad Khairul Azhar Abdul Razabc, Norehan Mokhtara, Nizuwan Azman ${ }^{d}$

aCraniofacial and Biomaterial Sciences Cluster, Advanced Medical and Dental Institute, Universiti Sains Malaysia, 13200 Bertam, Penang, Malaysia

bLaser Center, Universiti Teknologi Malaysia, 81310 UTM Johor Bahru, Johor, Malaysia

'School of Health Science, Universiti Sains Malaysia, Health Campus, 16150 Kubang Kerian, Kelantan, Malaysia

dResearch and Networking Division, Advanced Medical and Dental Institute, Universiti Sains Malaysia, 13200 Bertam, Penang, Malaysia
Article history

Received

9 April 2020

Received in revised form

12 October 2020

Accepted

21 October 2020

Published online

27 October 2020

*Corresponding author fatanah.suhaimi@usm.my

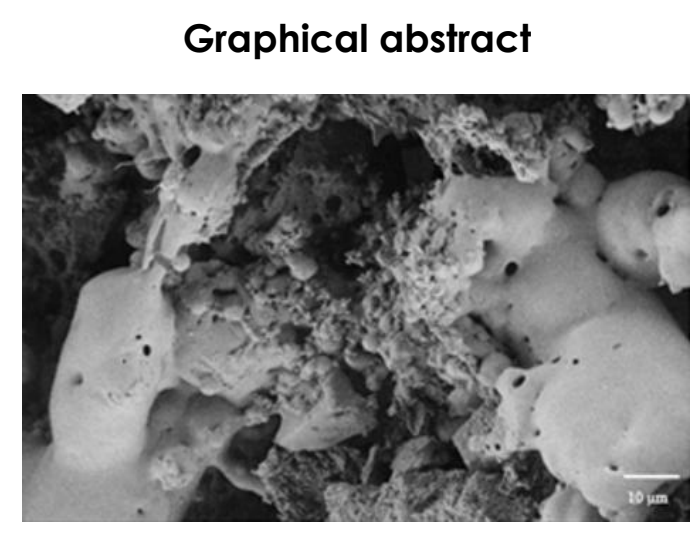

\begin{abstract}
Nd:YAG laser with a wavelength of $1064 \mathrm{~nm}$ has been used for various applications in dentistry, including for soft tissue and hard tissue applications. This study aimed to investigate the changes in morphological structures and elemental composition of enamel surface after composite removal using energy variations of $\mathrm{Nd}: Y A G$ laser. 12 healthy human premolar teeth were cut into half, and Blügloo adhesives were applied to the tooth surface. The samples were subjected to Nd:YAG laser irradiations with three different energy parameters, $510 \mathrm{~mJ}, 540 \mathrm{~mJ}$, and $580 \mathrm{~mJ}$. The changes in enamel surface morphology and composition of elements were analyzed using Field Emission Scanning Electron Microscopy (FESEM) and Energy Dispersive X-Ray (EDX). Surface morphology indicates that $540 \mathrm{~mJ}$ can potentially be used for composite adhesives removal. For the elemental composition, carbon, phosphorus, and calcium were statistically significant between samples without composite, after bracket debonding, and after laser irradiation. Several morphological changes may occur on the enamel surface after samples were irradiated with a laser. Energy parameter of the laser plays a vital role towards the desired surface. In this study, $540 \mathrm{~mJ}$ is seen to be potential for material removal process on the enamel surface.
\end{abstract}

Keywords: Nd:YAG laser, enamel, scanning electron microscopy, laser ablation, dental

Abstrak
Laser Nd:YAG dengan panjang gelombang $1064 \mathrm{~nm}$ telah digunakan untuk
pelbagai aplikasi dalam pergigian, termasuk aplikasi untuk tisu lembut dan 


\begin{abstract}
tisu keras. Kajian ini bertujuan untuk mengkaji perubahan struktur morfologi dan komposisi elemen permukaan enamel selepas penyingkiran komposit menggunakan variasi tenaga laser Nd:YAG. 12 gigi premolar manusia yang sihat dipotong menjadi setengah, dan pelekat Blūgloo telah diletakkan pada permukaan gigi. Sampel dikenakan sinaran laser Nd:YAG dengan tiga parameter tenaga yang berbeza, $510 \mathrm{~mJ}, 540 \mathrm{~mJ}$, dan $580 \mathrm{~mJ}$. Perubahan morfologi dan komposisi permukaan enamel telah dianalisis dengan menggunakan Mikroskopi Pengimbasan Pelepasan Elektronik (FESEM) dan Energy Dispersive X-Ray (EDX). Morfologi permukaan menunjukkan bahawa $540 \mathrm{~mJ}$ berpotensi digunakan untuk penyingkiran pelekat komposit. Untuk komposisi unsur, karbon, fosforus, dan kalsium didapati signifikan secara statistik di antara sampel tanpa komposit, selepas bukaan pendakap, dan selepas penyinaran laser. Beberapa perubahan morfologi berlaku di permukaan enamel selepas sampel disinari dengan laser. Tenaga laser memainkan peranan penting terhadap permukaan yang dikehendaki. Dalam kajian ini, $540 \mathrm{~mJ}$ dilihat berpotensi untuk menyingkirkan bahan pelekat pada permukaan enamel.
\end{abstract}

Kata kunci: Laser Nd:YAG, enamel, pemeriksaan mikroskop elektron, ablasi laser, pergigian

(C) 2020 Penerbit UTM Press. All rights reserved

\subsection{INTRODUCTION}

Lasers have been widely used in dentistry for various applications and dental procedures such as cavity preparation [1], caries removal [2] as well as diseased gingival tissues removal. The advantages of a laser during treatment, such as able to reduce pain, less time of treatment, and less vibration to the patient $[3,4]$, make it more favourable compared to the conventional approaches.

Four types of laser-tissue interactions that might happen after a laser beam reaches a tissue surface include reflection, refraction, scattering, absorption or transmission [5]. These different interactions probably occurred on the surface, depending on the optical properties of tissue and laser parameters used, such as energy, wavelength, pulse duration, and operation mode [6]. The penetration depth of laser radiation in the target surface also determines a laser's suitability for surgical procedures [7].

Photothermal effects, photochemical reactions, photomechanical interactions, and photoelectrical interactions are the examples of laser interaction mechanisms after biological interface occurs between laser light and target surface [8]. During laser irradiation, water molecules and organic components of biological tissues will selectively absorb the energy from the laser, which causes them to evaporate and produce heat (thermal energy) from the process called photothermal evaporations [9].

Photoablation is a kind of photothermal interaction that remove the material by the vaporization process. When laser light bombarded the target surface, the absorption of thermal energy happened on the surface and led to a heating process [10]. The heating condition eventually caused melting and vaporization of the target material [11]. The light effect from the photon results in temperature rise, which then converted into kinetic energy and formed vibrational relaxations and non-radiative processes [12].

Orthodontic treatment involves the use of braces that are bonded to the enamel surface with the help of arc wires threaded through the bracket [13]. Dental materials such as resin ionomer cement, composite resin fillings, and dental amalgam fillings function to bond the orthodontic brackets to the tooth surface [14]. During the material removal process, the laser acts as a medium to ablate the residual material from the enamel surface, instead of using mechanical and conventional techniques that can cause discernable damage to the tooth surface [15]. A study by Siniaeva et al. [16] indicates positive results of material removal using a microsecond Nd:YAG laser, without causing any severe damage to the tooth surface. Another study by Alexander et al. [17] showed that $355 \mathrm{~nm}$ laser pulses with a pulse width of 10 nanoseconds able to remove the composite adhesive through selective laser ablation.

However, choosing the correct laser energy parameter is crucial, particularly to prevent any microstructural damage to the enamel. Appropriate selection of laser exposure may efficiently remove materials while minimizing unnecessary exposure to the surrounding tissues. Additionally, composite materials produce various reactions to laser irradiation, such as the presence of bubbles, melting effect, recrystallization, evaporation, pores, and other outcomes $[13,16,18]$. Thus, the objective of this study is to investigate the morphological changes and elemental composition of the enamel surface 
following Nd:YAG laser removal of composite adhesives based on the energy variation of the laser.

\subsection{METHODOLOGY}

\subsection{Sample Preparation}

Twelve healthy and non-caries premolars were collected in this study. The teeth were extracted due to orthodontics procedure. The extracted teeth were collected at the Advanced Medical and Dental Institute (AMDI) dental clinics and stored in a $70 \%$ normal saline solution (B Braun, Germany) at the room temperature. The collection of the samples was approved by the Human Research Ethics Committee of the Universiti Sains Malaysia (USM). A random selection of teeth samples was done after the samples were cleaned from any caries and debris. The teeth were longitudinally sectioned into two parts, and the root parts were cut using a low-speed precision saw (Buehler, USA). After the cutting process was done, the teeth were mounted using Epofix solution (Struers, Denmark) to provide a stable and fixed position for the teeth samples. The bottom part of the mounted teeth was ground using MetaServ 250 Single Grinder-Polisher (Buehler, USA) of 600 Grit to flatten the surface. The rotation speed was $100 \mathrm{rpm}$, and the size of the abrasive papers was 8 inches.

Next, the enamel surface was etched with an etching solution (Ormco, CA) for 30 seconds and rinsed with a flow of tap water for 10 seconds. The sample was dried using a handheld dryer for 15 seconds. After the sample's surface had been dried, a thin layer of Ortho Solo primer (Ormco, CA) was applied to enhance the bonding. Then, a pea-size of Blūgloo adhesive (Ormco, CA) was applied to the dental brackets (3M Unitek, USA) to be bonded to the enamel surface. The bracket was pressed onto the enamel surface for approximately 1 minute to ensure the thickness of the material is as thin as possible. The estimated thickness of the adhesive material is $0.03 \mathrm{~mm}$ to $0.05 \mathrm{~mm}$.

After that, the adhesive material was cured with a LED curing light (TPC, CA) for 20 seconds to harden the material. The light intensity of the curing light was $1250 \mathrm{~mW} / \mathrm{cm}^{2}$. Bracket debonding process was done after the samples have been left for a week. Debonding plier (3M, USA) was used to debond the brackets. The tip of the debonding plier was placed against mesial and distal edges of bonding base, and the bracket wings were squeezed mesiodistally to pull the bracket from the tooth surface.

\subsection{Laser Irradiation}

Teeth samples were irradiated with Nd:YAG laser (Spectron Laser System, UK) with a wavelength of
$1064 \mathrm{~nm}$. The laser tip is positioned at $3 \mathrm{~cm}$ from the enamel surface. The spot diameter of the laser is 3 $\mathrm{mm}$. The pulse rate is set to $2 \mathrm{~Hz}$. A constant and fixed distance is important to ensure a consistent spot size for each ablated area, as shown in Figure 1. In this study, the energies used were $510 \mathrm{~mJ}, 540 \mathrm{~mJ}$, and $580 \mathrm{~mJ}$. Four samples were subjected to each energy level.

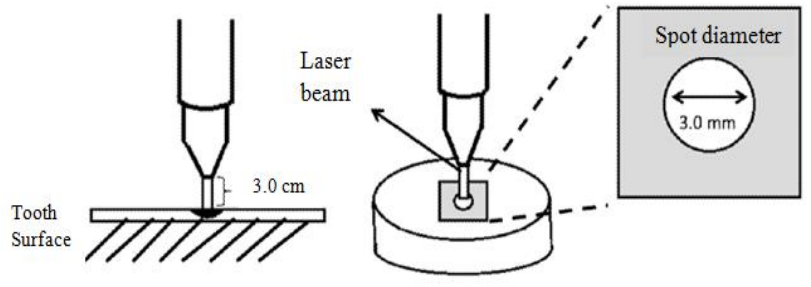

Figure 1 Laser irradiation setting

\subsection{Sample Analysis}

Samples analysis was done using a Field Emission Scanning Electron Microscope (FESEM) and Electron Dispersive X-ray Spectrometry (EDX). FESEM (FEI Nova NanoSEM 450, USA) was used to analyze the morphological surface of teeth samples visually, while EDX (FEI, USA) analysis was used to analyze the elemental composition of the samples. The morphology and the elemental composition data were compared between samples at the condition before applying the adhesive, after debonding process, and samples after Nd:YAG laser irradiation.

Percentage difference of the elemental composition was also calculated to identify any significant changes in the element when subject to laser irradiation. The percentage difference (PD) is calculated as:

$$
P D(\%)=\frac{\text { Element }_{(\text {after })}-\text { Element }_{(\text {before })}}{\text { Element }_{(\text {after })}+\text { Element }_{(\text {before })}} \times 100 \%
$$

The element is either carbon, oxygen, phosphorus or calcium, depending on the element of interest.

\subsection{Statistical Analysis}

Groups of data were expressed as means and standard deviation. P-value less than 0.5 is considered statistically significant. A paired samples t-test was used to compare the differences between groups of samples without adhesive, samples after debonding and samples after laser irradiation for each element. Analysis was conducted using Statistical Package for the Social Sciences (SPSS) (IBM Corporation, USA) software. 


\subsection{RESULTS AND DISCUSSION}

\subsection{Surface Morphology}

Figure 2(a) shows the surface morphology of a human tooth without adhesive material, selected from one of the samples in this study. Additionally, Figure 2(b) shows the human tooth after bracket debonding process. Tooth sample without adhesive showed a smooth and uniform surface. While in Figure 2(b), due to the presence of adhesive, the tooth sample appeared rougher and non-uniform texture can be seen throughout the sample surface.

After Nd:YAG laser irradiation, spots on the samples were captured to assess any different patterns produced on the sample surface. Figure 3 shows the surface morphology of the tooth sample after laser irradiation of 510,540 and $580 \mathrm{~mJ}$. After irradiated with $510 \mathrm{~mJ}$ of energy, the formation of holes is produced in the samples. The holes formation of the sample in Figure 3 are more profound and more extensive compared to the holes created in Figure 3 (b). The formation of holes is due to the exposure of laser irradiation on the desired area. The presence of bubbles also can be found in the surrounding exposure area, which defines the melting effect of adhesives has occurred. Both Figure 3(a) and Figure 3 (b) show that the adhesive materials were not fully removed during the irradiation process.

Figures 3(c) and 3(d) show the surface morphology of tooth samples after laser irradiation of $540 \mathrm{~mJ}$. Smooth texture for both samples with less indentation on the surface can be seen on the tooth sample after it has been irradiated with $540 \mathrm{~mJ}$. The teeth surface showed a scattered grain pattern, which indicates potential complete removal of the adhesives on the irradiated area. Samples irradiated with $580 \mathrm{~mJ}$ of energy produced a surface with nonuniformity and rough texture, as seen in Figure 3(e). Whereas, another sample had holes with amorphous grain surface, as shown in Figure 3(f). Based on the changes found in enamel's microstructures after laser irradiation, the results in this study are similar to the expected outcome.

Enamel surface was expected to undergo few physical changes such as the formation of holes or bubble-like structures, numerous pores, pits and fissures after laser irradiation [19, 20]. A study by AlJedani et al. [21] showed that the original microstructure of the enamel rod might change and became irregular in shape due to the melting of the surface after laser exposure. Additionally, the appearance of pores and bubbles may also exist [22]. The presence of small shallow cavities surrounds enamel granules are the characteristics found on enamel surface after irradiated with Nd:YAG laser [23].

The resulting structure of the tooth sample highly depends on the irradiation energy exposed to the sample, surface and structure of the target.
Eventhough same laser energy has been exposed to a sample, the results for both laser irradiation may not be the same. Both surfaces produced a different level of depth penetration and variation in enamel's morphological changes after laser exposure. This is due to the difference of the material's thickness on the convex surface of the enamel [13]. This condition influenced the laser penetration level on the material and enamel surface, thus results in varies melting effect in the material removal process.

\subsection{Elemental Composition}

In this study, four main elements exist in all samples, which are carbon $(\mathrm{C})$, oxygen $(\mathrm{O})$, phosphorus $(\mathrm{P})$ and calcium (Ca). Table 1, 2 and 3 show the elemental composition by weighted percentage (wt.\%) and atomic percentage (at.\%) for each element that had been identified on the samples without adhesive, samples with adhesive after bracket debonds process and samples after laser irradiation of $510 \mathrm{~mJ}, 540 \mathrm{~mJ}$ and $580 \mathrm{~mJ}$.

In the samples without adhesive, the elemental composition represents the composition of the tooth samples itself without any modifications. At this stage, oxygen is the most abundant element in all samples, followed by calcium. On the other hand, carbon is the least element in all samples. Interestingly, phosphorus and calcium are not detected in the samples after bracket debonds process. Additionally, the percentages of carbon are primarily increased in the samples after bracket debond process. The increased carbon percentage indicates that the tooth surface has been applied with an adhesive material, and a portion of the adhesive material remains on the tooth surface after bracket debond process.

After laser irradiation, carbon is expected to increase due to the ablation process. In this study, it is observed that carbon is higher after laser irradiation compared to the original tooth condition (without adhesive). The percentage of oxygen after irradiation is relatively similar to its original condition. However, the percentage of phosphorus and calcium is varied for all the samples, as shown in Table 1-3.

Table 4 shows the percentage differences of carbon $(C)$, oxygen $(O)$, phosphorus $(P)$ and calcium (Ca) comparing before bracket bonding process and after laser irradiation for laser energy parameters of $510 \mathrm{~mJ}, 540 \mathrm{~mJ}$, and $580 \mathrm{~mJ}$. The percentage difference of carbon is the highest for samples irradiated with $580 \mathrm{~mJ}$ with $72.90 \%$, while oxygen has the highest percentage difference after irradiated with $510 \mathrm{~mJ}$. Both phosphorus and calcium have the most percentage differences in the energy of $510 \mathrm{~mJ}$, with $97.30 \%$ and $97.83 \%$, respectively.

For most samples, the weighted percentage of carbon increased in tooth sample with composite adhesives compared to sample without adhesive. 
The increasing percentage of carbon is due to the presence of the composite adhesives on the surface. Blūgloo composite adhesive contains about 10-20 wt.\% of bisphenol A diglycidyl ether methacrylate (BADGE), which is a large molecular methacrylate monomer used in most composite adhesives [24]. The molecular formula of BADGE is $\mathrm{C}_{21} \mathrm{H}_{24} \mathrm{O}_{4}$, which contributes to the presence of carbon element in the composite adhesives.

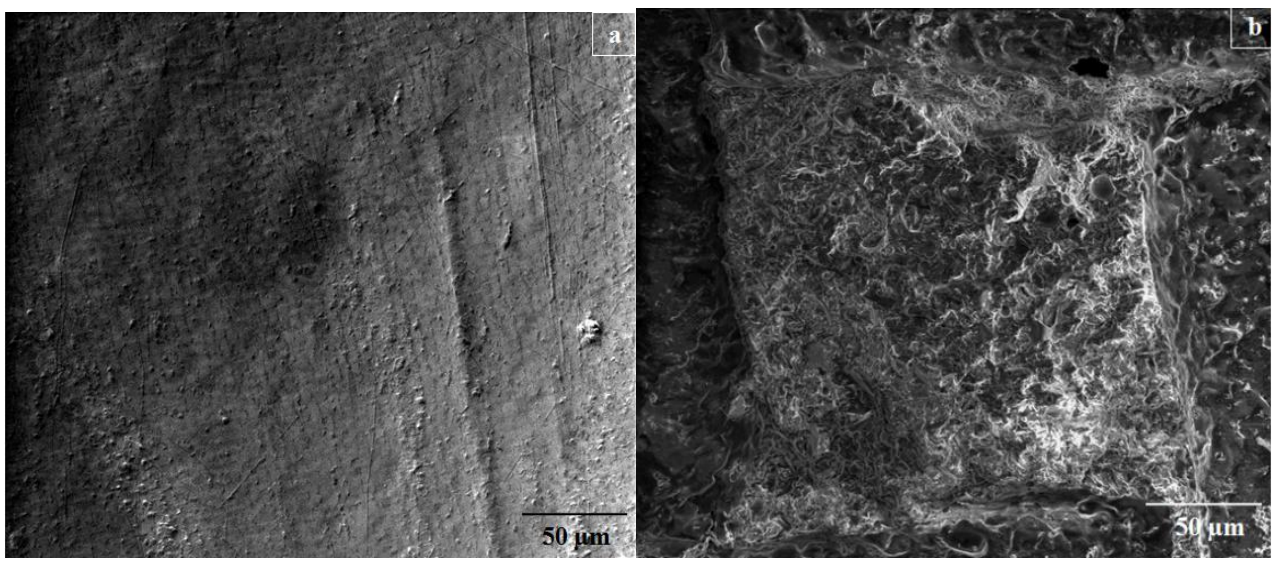

Figure 2 Surface morphology of a tooth (a) without adhesive, and (b) with adhesives after bracket debonding process (1kx magnification)

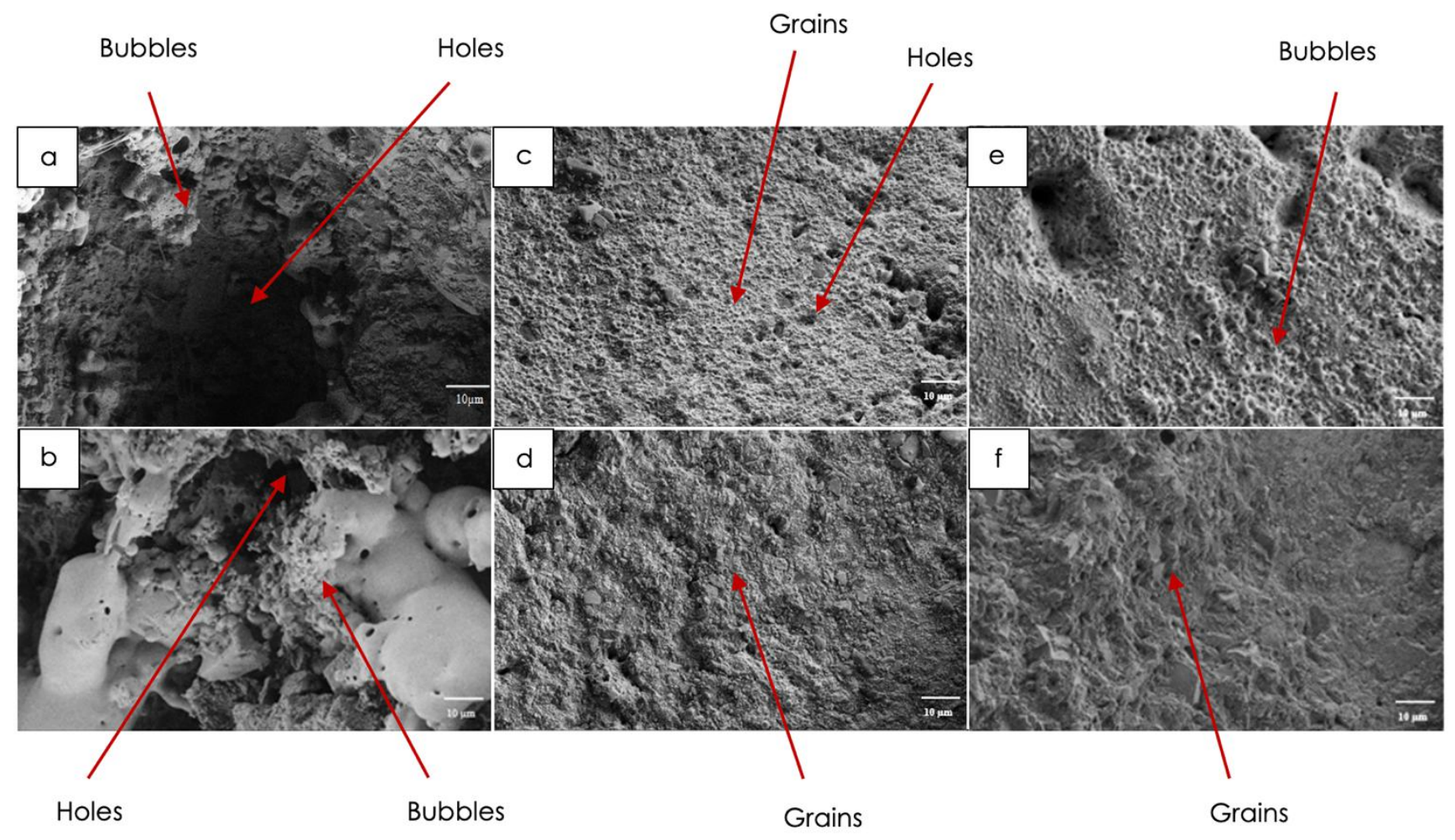

Figure 3 Surface morphology of tooth sample after laser irradiation with energy of $510 \mathrm{~mJ}(\mathrm{a}, \mathrm{b}), 540 \mathrm{~mJ}(\mathrm{c}, \mathrm{d})$, and $580 \mathrm{~mJ}(\mathrm{e}, \mathrm{f})(1 \mathrm{kx}$ magnification)

However, after laser irradiation, the carbon percentage in all samples were reduced. The decreasing rate of carbon after laser irradiation indicates that material removal occurred on the sample. The heating from laser light might cause the enamel to melt on surfaces and eventually reduced a significant amount of carbonate content of hydroxyapatite. This condition makes enamel more 
resistant to demineralization $[25,26]$. Based on the ablation methodologies concepts, the adhesive absorbs a portion of energy during the absorption process. The adhesives will then become carbonized and led to the removal of the adhesive material from the surface [13].

\subsection{Statistical Analysis}

Means and standard deviations of carbon, oxygen, phosphorus and calcium were calculated in samples without adhesive, samples with adhesive after bracket debond and samples after laser irradiation. A paired t-test was carried out for each sample to find out the significant difference for each element in the samples. Table 5 shows the statistical analysis of carbon, oxygen, phosphorus and calcium for the samples after debonding compared to the samples without adhesive. Carbon increased significantly with a $p$-value of $0.002(p<0.05)$. Both phosphorus and calcium also increased with p-values of 0.000 and 0.010 , respectively.

Table 1 Elemental composition by weighted percentage (wt.\%) and atomic percentage (at.\%) for each element on the sample without adhesive, after bracket debond and after laser irradiation of $510 \mathrm{~mJ}$

\begin{tabular}{ccccccc}
\hline Element & \multicolumn{2}{c}{$\begin{array}{c}\text { Without } \\
\text { Adhesive }\end{array}$} & \multicolumn{2}{c}{$\begin{array}{c}\text { After Bracket } \\
\text { Debond }\end{array}$} & \multicolumn{2}{c}{$\begin{array}{c}\text { After Laser } \\
\text { Irradiation }\end{array}$} \\
& wt. \% & at. \% & wt.\% & at.\% & wt.\% & at.\% \\
\hline $\mathrm{C}$ & 4.87 & 8.66 & 36.54 & 46.10 & 5.94 & 10.10 \\
$\mathrm{O}$ & 46.88 & 62.60 & 47.82 & 45.29 & 41.65 & 53.21 \\
$\mathrm{P}$ & 17.26 & 11.90 & 0.00 & 0.00 & 0.23 & 0.15 \\
$\mathrm{Ca}$ & 30.14 & 16.06 & 0.00 & 0.00 & 0.33 & 0.17 \\
\hline
\end{tabular}

Table 2 Elemental composition by weighted percentage (wt.\%) and atomic percentage (at.\%) for each element on the sample without adhesive, after bracket debond and after laser irradiation of $540 \mathrm{~mJ}$

\begin{tabular}{ccccccc}
\hline Element & \multicolumn{2}{c}{$\begin{array}{c}\text { Without } \\
\text { Adhesive }\end{array}$} & \multicolumn{2}{c}{$\begin{array}{c}\text { After Bracket } \\
\text { Debond }\end{array}$} & \multicolumn{2}{c}{$\begin{array}{c}\text { After Laser } \\
\text { Irradiation }\end{array}$} \\
& wt. \% & at. \% & wt.\% & at.\% & wt.\% & at.\% \\
\hline $\mathrm{C}$ & 7.99 & 15.24 & 40.17 & 42.47 & 29.43 & 30.98 \\
$\mathrm{O}$ & 33.58 & 48.05 & 10.00 & 25.01 & 35.94 & 25.94 \\
$\mathrm{P}$ & 18.74 & 13.85 & 0.00 & 0.00 & 6.54 & 3.66 \\
$\mathrm{Ca}$ & 38.90 & 22.22 & 0.00 & 0.00 & 13.11 & 5.67 \\
\hline
\end{tabular}

Table 3 Elemental composition by weighted percentage (wt.\%) and atomic percentage (at.\%) for each element on the sample without adhesive, after bracket debond and after laser irradiation of $580 \mathrm{~mJ}$

\begin{tabular}{ccccccc}
\hline Element & \multicolumn{2}{c}{$\begin{array}{c}\text { Without } \\
\text { Adhesive }\end{array}$} & \multicolumn{2}{c}{$\begin{array}{c}\text { After Bracket } \\
\text { Debond }\end{array}$} & \multicolumn{2}{c}{$\begin{array}{c}\text { After Laser } \\
\text { Irradiation }\end{array}$} \\
& wt. \% & at. \% & wt.\% & at.\% & wt.\% & at.\% \\
\hline C & 5.22 & 10.23 & 33.30 & 43.02 & 33.12 & 47.31 \\
O & 34.44 & 50.62 & 46.64 & 45.49 & 32.74 & 34.92 \\
P & 19.33 & 14.69 & 0.00 & 0.00 & 12.99 & 3.83 \\
Ca & 40.29 & 23.67 & 0.00 & 0.00 & 6.96 & 5.80 \\
\hline
\end{tabular}

Table 4 Percentage differences of carbon (C), oxygen (O), phosphorus (P) and calcium (Ca) comparing after laser irradiation and before bracket bonding process for various laser energy

\begin{tabular}{ccccc}
\hline Energy $(\mathbf{m J})$ & $\mathbf{C}$ & $\mathbf{O}$ & $\mathbf{P}$ & $\mathbf{C a}$ \\
\hline 510 & 9.90 & 5.91 & 97.30 & 97.83 \\
540 & 57.28 & 3.39 & 48.26 & 49.59 \\
580 & 72.90 & 2.53 & 19.62 & 70.54 \\
\hline
\end{tabular}

Additionally, Table 6 shows the statistical analysis comparing the samples after bracket debond and samples after laser irradiation. There were significant changes in carbon, phosphorus, and calcium, where carbon increased with p-values of 0.021 , phosphorus with 0.049 and calcium with 0.043 .

Table 5 Statistical analysis of carbon, oxygen, calcium and phosphorus for samples without adhesive and after debonding for energy variation

\begin{tabular}{cccccc}
\hline & $\begin{array}{c}\text { Without } \\
\text { Adhesive } \\
\text { Mean } \\
\text { (SD) }\end{array}$ & $\begin{array}{c}\text { Affer } \\
\text { Debond } \\
\text { Mean } \\
\text { (SD) }\end{array}$ & $\begin{array}{c}\text { Mean of } \\
\text { Score } \\
\text { Difference } \\
(95 \% \text { Cl) }\end{array}$ & $\begin{array}{c}\text { T Stat }^{\mathbf{a}} \\
\text { (df) }\end{array}$ & $\begin{array}{c}\mathbf{P} \\
\text { Value } \\
\mathbf{a}\end{array}$ \\
\hline $\mathrm{C}$ & 12.8 & 42.6 & -29.8 & $-5.4(6)$ & 0.002 \\
& $(13.2)$ & $(7.5)$ & $(-43.3,-16.2)$ & & \\
\hline $\mathrm{O}$ & 44.0 & 38.8 & 5.2 & $1.2(6)$ & 0.284 \\
& $(8.2)$ & $(13.1)$ & $(-5.5,15.8)$ & & \\
\hline $\mathrm{P}$ & 15.3 & 0.1 & 15.2 & $9.9(6)$ & 0.000 \\
& $(4.0)$ & $(0.2)$ & $(11.4,18.9)$ & & \\
\hline $\mathrm{C}$ & 22.7 & 0.0 & 22.8 & $3.7(6)$ & 0.010 \\
$\mathrm{a}$ & $(16.1)$ & $(0.1)$ & $(7.8,37.7)$ & & \\
\hline aPaired t-test & & & &
\end{tabular}

Table 6 Statistical analysis of carbon, oxygen, calcium and phosphorus for samples between after debonding and after laser irradiation for energy variation

\begin{tabular}{cccccc}
\hline & $\begin{array}{c}\text { After } \\
\text { Debond } \\
\text { Mean } \\
(\text { SD) }\end{array}$ & $\begin{array}{c}\text { After } \\
\text { Laser } \\
\text { Mean } \\
(\text { SD) }\end{array}$ & $\begin{array}{c}\text { Mean of } \\
\text { Score } \\
\text { Difference } \\
(95 \% \text { Cl) }\end{array}$ & $\begin{array}{c}\text { T Staf }^{\mathbf{a}} \\
(\mathbf{d f})\end{array}$ & $\begin{array}{c}\mathbf{P} \\
\text { Value } \\
\mathbf{a}\end{array}$ \\
\hline $\mathrm{C}$ & 42.6 & 22.7 & 19.9 & $3.1(6)$ & 0.021 \\
& $(7.5)$ & $(16.9)$ & $(4.1,35.6)$ & & \\
\hline $\mathrm{O}$ & 38.8 & 34.1 & 4.7 & $0.9(6)$ & 0.402 \\
& $(13.1)$ & $(4.9)$ & $(-8.1,17.5)$ & & \\
\hline $\mathrm{P}$ & 0.1 & 6.2 & -6.2 & $-2.5(6)$ & 0.049 \\
& $(0.2)$ & $(6.5)$ & $(-12.3,0.0)$ & & \\
\hline $\mathrm{C}$ & 0.0 & 16.7 & -16.7 & $-2.6(6)$ & 0.043 \\
$\mathrm{a}$ & $(0.0)$ & $(17.2)$ & $(-32.6,-0.7)$ & & \\
\hline aPaired t-test & & & &
\end{tabular}

Table 7 shows the statistical analysis of changes in carbon, oxygen, calcium and phosphorus of the samples between after debonding and after laser irradiation based on the energy of the laser. Using multiple post-hoc comparison (Tukey HSD), there was a significant mean difference for carbon between the energy of 580,540 and $510 \mathrm{~mJ}$ ( $\mathrm{p}$-value<0.05). The result indicates a higher mean difference 
between the energy of $510 \mathrm{~mJ}$ and $580 \mathrm{~mJ}$ compared to the energy of $540 \mathrm{~mJ}$ and $580 \mathrm{~mJ}$.

Table 7 Statistical analysis of change in carbon, oxygen, calcium and phosphorus of the samples between after debonding and after laser irradiation based on the energy of the laser

\begin{tabular}{ccccc}
\hline & $\begin{array}{c}\text { Energy } \\
(\mathbf{m J})\end{array}$ & Mean (SD) & $\mathbf{( 9 5 \% ~ C l )}$ & P Value $^{\text {a }}$ \\
\hline $\mathrm{C}$ & 510 & $-24.3(58.0)$ & $-72.71,24.2$ & \\
& 540 & $-12.1(43.2)$ & $-48.2,24.0$ & $<0.001$ \\
& 580 & $14.1(23.1)$ & $-5.23,33.37$ & \\
\hline $\mathrm{O}$ & 510 & $-10.0(12.2)$ & $-20.2,0.3$ & \\
& 540 & $-20.2(25.9)$ & $-41.9,1.4$ & 0.303 \\
& 580 & $-20.3(10.9)$ & $-29.3,-11.2$ & \\
\hline $\mathrm{P}$ & 510 & $-50.0(53.6)$ & $-94.9,-5.2$ & \\
& 540 & $-45.2(58.7)$ & $-94.3,3.9$ & 0.344 \\
& 580 & $-47.9(55.9)$ & $-94.6,-1.1$ & \\
\hline Ca & 510 & $-36.6(53.9)$ & $-81.6,8.5$ & \\
& 540 & $-40.4(64.3)$ & $-94.2,13.3$ & 0.578 \\
& 580 & $-48.4(55.3)$ & $-94.6,-2.2$ & \\
\hline aMultiple post-hoc comparison (Tukey HSD) &
\end{tabular}

\subsection{CONCLUSION}

Several morphological changes occurred on the enamel surface after samples were irradiated with various laser energy parameters. Based on the results, the effectiveness of material removal on the enamel surface highly depends on the irradiation energy level. As seen from this study, $510 \mathrm{~mJ}$ is insufficient to remove the adhesive material. However, $540 \mathrm{~mJ}$ of energy can potentially be used for this purpose. Additionally, other factors such as the thickness of the adhesive material, and adhesive material composition applied on the tooth surface may also influence the material removal process. Further investigation is required to study the effect of higher energy and ablation concepts on the enamel surface.

\section{Acknowledgement}

The authors would like to acknowledge the support provided by the Craniofacial and Biomaterial Sciences Cluster, Advanced Medical and Dental Institute, Universiti Sains Malaysia (USM) and the School of Materials and Mineral Resources Engineering, USM for providing materials and equipment for this research. This study was funded by the Short Term Grant from the Universiti Sains Malaysia (Project No: 6312141).

\section{References}

[1] Prathima, G. S., Bhadrashetty, D., Umesh Babu, S. B., and Disha, P. 2015. Microdentistry with Lasers. J Int. Oral Health. 7(9): 134-137.
[2] Rezaei, Y., Bagheri, H., and Esmaeilzadeh, M. 2011. Effects of Laser Irradiation on Caries Prevention. J Lasers Med. Sci. 2(4): 159-164.

[3] Ishikawa, I., Aoki. A., Takasaki. A. A., Mizutani, K., Sasaki, K. M., and Izumi, Y. 2009. Application of Lasers in Periodontics: True Innovation or Myth? Periodontology. 50: 90-126. DOI: https://doi.org/10.1111/j.1600-0757.2008.00283.x.

[4] Walsh, L. J. 2003. The Current Status of Laser Applications in dentistry. Aust Dent. J. 48(3): 146-155. DOI: https://doi.org/10.1111/j.1834-7819.2003.tb00025.x.

[5] Baxter, G. D. 1994. Therapeutic Lasers: Theory and Practice. New York: Churchill Livingstone.

[6] Ashour, H. S. 2006. Tuning Semiconductor Laser Diode Lasing Frequency and Narrowing the Laser Linewidth Using External Oscillating Driving Field. J Applied Sci. 6(10): 22092216.

DOI: https://doi.org/10.3923/jas.2006.2209.2216.

[7] Kulikov, K. 2014. Laser Interaction with Biological Material, Biological and Medical Physics, Biomedical Engineering. Switzerland: Springer International Publishing. DOI: https://doi.org/10.1007/978-3-319-01739-6.

[8] Mensudar, R., Anuradha. B., Mitthra, S., Chandra, M. A., and Panneer, S. V. 2017. Lasers - An Asset to Endodontics. International Journal of Current Research. 9(10): 5980559809.

[9] Rodríguez-Vilchis, L. E., Contreras-Bulnes, R., Olea-Meji 'a, O. F., Sa'nchez-Flores, I., and Centeno-Pedraza, C. 2011. Morphological and Structural Changes on Human Dental Enamel After Er:YAG Laser Irradiation: AFM, SEM, and EDS Evaluation. Photomed Laser Surg. 29 (7): 493-500. DOI: https://doi.org/10.1089/pho.2010.2925.

[10] St-Onge, L., Detalle, V., and Sabsabi, M. 2002. Enhanced Laser-induced Breakdown Spectroscopy using the Combination of Fourth-harmonic and Fundamental Nd:YAG Laser Pulses. Spectrochemica Acta Part B: Atomic Spectroscopy. 57: 121-135. DOI : https://doi.org/10.1016/S0584-8547(01)00358-5.

[11] Afrin, N., Ji, P., Chen, J. K., and Zhang, Y. 2016. Effects of Beam Size and Pulse Duration on the Laser Drilling Process. Heat Transfer Summer Conference. DOI: https://doi.org/10.1115/HT2016-7339.

[12] Smith, S. E. 2012. Differential Laser-induced Pertubation Spectroscopy for Analysis of Biological Material. Dissertation, University of Florida.

[13] Zulkifli, N., Suhaimi, F. M., Razab, M. K. A. A., Jaafar, M. S., Mokhtar, N. 2015. The Use of Nd:YAG Laser for Ablation of Dental Material. 5th International Conference on Biomedical and Technology (ICBET 2015). 81: 40-47. DOI: https://doi.org/10.7763/IPCBEE. 2015. V81. 8.

[14] Lohbaver, U. 2010. Dental Glass lonomer Cements as Permanent Filling Materials? - Properties, Limitations and Future Trends. Materials. 3: 76-96.

DOI: https://doi.org/10.3390/ma3010076.

[15] Campbell, P. M. 1995. Enamel Surfaces After Orthodontic Bracket Debonding. Angle Orthod. 65(2): 103-1 10.

[16] Siniaeva, M. L., Siniavsky, M. N., Pashinin, V. P., Mamedov, A. A., Konov, V. I., and Kononenko, V. V. 2009. Laser Ablation of Dental Materials Using a Microsecond Nd: Yag Laser. Laser Physics. 19(5):1 056-1060. DOI: https://doi.org/10.1134/S1054660X09050314.

[17] Alexander, R., Xie, J., and Fried, D. 2002. Selective Removal of Residual Composite from Dental Enamel Surfaces Using the Third Harmonic of a Q-switched Nd: YAG Laser. Lasers in Surg. Med. 30(3): 240-245. DOI: https://doi.org/10.1002/lsm.10018.

[18] Gimbel, C. B. 2000. Hard Tissue Laser Procedures. Dental Clinics of North America. 44(4): 931-953.

[19] Souza-Gabriel, A. E., Chinelatti, M. A., Borsatto, M. C. Pecora, J. D., Palma-Dibb, R. G., and Corona, S. A. 2008. SEM Analysis of Enamel Surface Treated by Er:Yag Laser: Influence of Irradiation Distance. Microsc. Res. Tech. 71: 536-541. 
DOI: https://doi.org/10.1002/jemt.20583.

[20] Navarro, R. S., Gouw-Soares, S., Cassoni, A. Haypec, P., Zezell, D. M., and de Paula Eduardo, C. 2010. The Influence of Erbium:yttrium-aluminum-garnet Laser Ablation with Variable Pulse Width on Morphology and Microleakage of Composite Restorations. Lasers Med. Sci. 25: 881-889. DOI: https://doi.org/10.1007/s10103-009-0736-6.

[21] Al-Jedani, S., Al-Hadeethi, Y., Ansari, M. S., and Razvi, M. A. N. 2016. Dental Hard Tissue Ablation with Laser Irradiation. Austin Dent. Sci. 1(1): 1007.

[22] Takeda, F. H., Harashima, T., E†o, J. N., Kimura, Y., and Matsumoto, K. 1998. Effect of Er:YAG Laser Treatment on the Root Canal Walls of Human Teeth: A SEM Study. Endod Dent. Traumatol. 14: 270-273.

DOI: https://doi.org/10.1111/j.1600-9657.1998.tb00851.x.
[23] Myaki, S., Watanabe, I. S., Eduardo, C. P., and Issáo, M. 1998. Nd: YAG Laser Effects on the Occlusal Surface of Premolars. Am. J Dent. 11(3): 103-105.

[24] Phan, X., Akyalcin, S., Wiltshire, W. A., and Rody, W. J. Jr. 2012. Effect of Tooth Bleaching on the Shear Bond Strength of a Fluoride-releasing Sealant. Angle Orthod. 82(3): 546-551. DOI: https://doi.org/10.2319/05271 1-353.1.

[25] Huang, G. F., Lan, W. H., Guo, M. K., and Chiang, C. P. 2001. Synergystic Effect of Nd:YAG Laser combined with Fluoride Varnish on Inhibition of Caries Formation in Dental Pits and Fissures in Vitro. J Formos Med Assoc. 100: 181-185.

[26] Hussain, N. 2012. Nd: yag \& Er:yag Lasers in Prevention and Conditioning of Enamel. Energy Procedia. 19: 192-198. DOI: https://doi.org/10.1016/j.egypro.2012.05.199. 